\title{
Territory of Hawaii
}

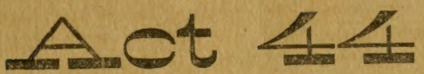

TO PROVIDE FOR THE ENCOURAGEMENT OF

Agriculture, Horticulture and Forestry

$A N D$

Appropriations for same Passed by the

Legislature of 1903.

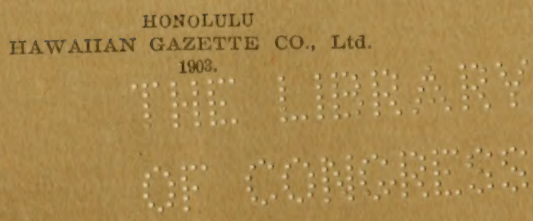




\section{9 \\ $\frac{2}{1903}$}

FEB 4 of 1204
D. of

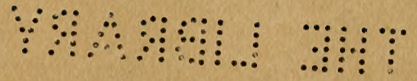

ओओ औ 




\section{AcT 44.}

An Act to Provide for the Encouragement and Protection of Agriculture, Horticulture and Forestry.

Be it Enacted by the Legislature of the Territory of Hawaii.

\section{DEFINITION.}

Section I. Whenever in this Act the word "Board" is used it shall refer and mean the Board of Commissioners of Agricultwire and Forestry, by this Act provided for.

\section{APPOINTMENT OF COMMISSIONERS.}

Sertion 2. There shall be a Board of Commissioners of Agricilture and Forestry of five members, who shall be appointed by the Governor by and with the advice and consent of the Senate.

The Superintendent of Public Works of the Territory shall be e.r officio a member of said Board, with the same powers and dnties herein prescribed for the other members of said Board, except as otherwise herein provided.

One of said Commissioners shall be appointed to hold office for one year, one for two years, one for three years, one for four years, and one for five years from January Ist, 1904.

Upon the expiration of the respective terms of the said Comnissioners, their respective successors shall be respectively appointed for a term of five years.

Upon a vacancy occurring in said board, a Commissioner shall be appointed to fill such vacancy for the remainder of the unexpired term.

\section{ORGANIZATION OF BOARD.}

Secrion 3. Immediately upon their appointment the Commissioners shall elect one of their members President and another 
Secretary of the Board. The Board shall have power to, from time to time, change its officers. A majority of the members of said Board shall constitute a quorum thereof, with power to transact any business within the powers or jurisdiction of the Board.

\section{EXPENSES OF·BOARD.}

SECTION 4. The members of the Board appointed under this Act, shall serve without pay. The Superintendent of Public Works shall receive no pay for services performed by him under the terms of this Act other than the salary appropriated by the Legislature for his said office of Superintendent of Public Works.

The Board shall be entitled to pay the traveling expenses within the Territory of its members, when actually engaged in business relating to the work of the Commission, and also all cost of postage, stationery, correspondence, records, printing, and other expenses necessarily or properly incidental to the business of the Bnard.

\section{DUTIES OF THE BOARD.}

Section 5. It shall be the duty of the Board:

(1) Information and Statistics. To gather, compile, tabulate, furnish and publish, from time to time, information and statistics.

(a) Foreslry. Concerning the area, location, character and natural and artificial increase of forests, and the natural, artificial and accidental decrease of the same, in the Territory of Hawaii, and to prepare and publish maps illustrating the same as far as possible;

And also concerning the best kinds of trees, plants and shrubs to plant in different localities, suggestions for the care and propagation of trees and shrubs both from an economic and an ornamental standpoint, and other useful information of a similar character, which the Board in its discretion may deem proper.

(b) Entomology and Plant Pathology. Concerning insects, scales, blights and diseases injurious, or liable to become inju- 
rious, to trees, plants or other vegetation, the ways and means of exterminating such pests and diseases aforesaid as are already in the Territory and preventing the introduction of those not yet here.

(c) General Agriculture. Concerning fruits, fibres, and useful or ornamental plants and their introduction, development and care, and concerning the manufacture or exportation of the same with a view to introducing, establishing and fostering new and valuable piants and industries.

(d) Co-operation with other Organizations. The Board shall in all $r$ espects endeavor, as far as possible, to encourage, work in harmony and co-operate with, the Federal Agricultural Experiment Station established in this Territory, and with all private persons or organizations doing work of an experimental or educational character, coming within the scope of the subject matters of this Act, and to avoid, as far as practicable, duplicating the work of such person or organization.

(2) Library. To secure copies of the laws of other states, territories and countries, and other publications germane to the subject matter of this Act, and make the same available for public information and consultation.

(3) Rules and Regulations. To make rules and regulations, and to amend the same from time to time in their discretion, stibject to the approval of the Governor, for and concerning the introduction, transportation and propagation of trees, shrubs and plants and the preservation, protection, extension and utilization of forests and forest reserves, both natural and artificial; for the quarantine, inspection, fumigation, disinfection, exclusion or déstruction, either upon introduction into this Territory, or at any time or place within the Territory, of any soil, nursery stock, tree, sugar cane, shrub, plant, flower, vine, cutting, graft, cion, bud, seel, rot, fruit pit, fruit, vegetable, leaf, nut, or other vegetable growth or other substances, and any box, barrel, package or packing material or containers in which said articles or any of them have been transported or contained which is or may be infected with or liable to assist in the transmission or dissemina- 
tion of any insect, blight, scale or disease injurious, or liable to become injurious to trees, plants or other vegetation of value. .

Included therein may be rules and regulations governing the shipping between the different islands of this Territory of any or all of the nursery stock, trees and other articles in this sub-section herein above enumerated:

And also with power to prohibit the importation into the Territory from any or all foreign countries, or other parts of the United States, or the shipment from one island within the Territory to another island therein, of any specific article, or class of articles above enumerated, which are liable to introduce or dissemminate, or assist in the introduction or dissemination of any insect, blight, scale or disease, injurious, or liable to become injurious to trees, plants, or other vegetation of value.. All rules and regulations made as aforesaid shall have the force and effect of law.

(4) Superintendent of Forestry Department. To appoint a Superintendent of Forestry, who shall have charge, direction and control (subject to the direction and control of the Board) of all matters relating to forestry, mentioned in or coming within the scope of this Act, and such other matters as the Board may from time to time direct; and who shall be paid such salary as may be appropriated by the Legislature.

Foresters 'To appoint and commission in each district of the Territory, one or more foresters, and the same at their pleasure to remove, whe shall serve without pay, to assist the Board to carry out the terms and intent of this law.

Said Superintendent of Forestry shall be a trained and educated forester, who shall have made the subject of forestry a special study, and if sueh a man is available, one who has had practical training and experience in connection with forestry in a tropical country.

Assistants and Rangers. To appoint, remove and fix the compensation of assistant Foresters and Forest Rangers, who shall have police powers in and concerning all matters relating to or connected with forests or forest reservations and the enforcement 
of any of the provisions of this Act, and such other persons as the Commission may employ.

(5) Care of Forestry Reserzations. To have the care, custody, control and regulation of all lands which may be set apart as forest reservations, under the terms of this Act.

(6) Protection of Forests and Water Suppiy To devise ways and means of protecting, extending, increasing and utilizing the forests and forest reserves, more particularly for protecting and developing the springs, streams and sources of water supply, so as to increase and make such water supply available for use.

(7) Self-Support of Forests. To devise and carry into operation, ways and means by which forests and forest reservations can, with due regard to the main objects herein set forth, be made self-supporting in whole or in part.

(8) Fencing and Exclusion of Stock. To secure as speedily as possible, either by private co-operation or by public appropriation, the erection and maintenance of fences to exclude live stock from forest reservations, and the removal from such reservations of the live stock running thereon, including the killing the same if necessary.

(9) Superintendent of Entomological Department. To appoint a Superintendent of Entomology, who shall have charge, direction and control (subject to the direction and control of the Board) of all matters relating to the exclusion or eradication of insects, scales, blights and diseases injurious, or liable to become iniurious, to trees, plants or other vegetation of value; and relating to the quarantine, inspection, disinfection, exclusion or destruction of any plant. article or substance injurious, or liable to become injurious to trees, plants or other vegtation of value mentioned in or coming within the scope of this Act, and of such other matters as the Board nay from time to time direct; and who shall be paid such salary as may be appropriated by the Legislature.

The said Superintendent of Entomology shall be a trained and educated Entomologist, who has made the subject of Entomology as related to Agriculture a special study; and, if such a man is 
available, one who has had practical training and experience in connection with Entomology in a tropical country.

(10) Assistant Entomologists and Inspectors. To appoint and commission one or more Assistant Entomologists, one of whom shall be selected especially for his fitness to procure from abroad beneficial insects and growths for the eradication of insects, blights, scales and diseases injurious to vegetation of value and for the destruction of injurious vegetation; and such Inspectors and other employees as may be necessary for the proper carrying into effect of this Act, and the same at their pleasure to remove, and to fix the compensation of said Assitsant Entomologists anả Inspectors..

(II) Buildings and Apparatus. To provide such buildings, grounds, apparatus and appurtenances as may be necessary or proper for the examination, quarantine, inspection and fumigation provided for by this Act; and for the obtaining, propagation, study and distribution of beneficial insects, growths and antidotes for the eradication of insects, blights, scales or diseases injurious to vegetation of value and for the destruction of injurious vegetation; and also any other apparatus or appurtenances necessary or proper for the purposes of carrying this Act into execution.

(12) Conflict of Authority. The several Superintendents and other officers appointed under the terms of this Act shall act in harmony and co-operate with each other; but in case any question involving a conflict of authority shall arise, the Board shall decide the same, and such decision shall be final.

(13) Supervision of Expenditures and Records. To supervise and direct all officers and employees authorized by this Act and the expenditures of all moneys appropriated for the purposes set forth in this Act, and of the special fund herein provided for. All receipts, expenditures and proceedings of the Board shall be duly recorded in proper books of record and account, and moneys shall be paid out only on proper vouchers in accordance with law, and upon the counter-signature of the Superintendent of Public Works. 
(14). Further Legislation. To formulate and from time to time recommend to the Governor and Legislature of the Territory such additional legislation as they deem necessary or desirable for the the better securing of the objects of this law.

(15) Annual Reports. To make and publish, at the end of each year, a report of the expenditures and proceedings of the Board and of the results achieved by the Board, together with such other matters as are germane to the subject matter of this Act, and which the Board may deem proper.

RESERVATION OF GOVERNMENT LAND FOR FORESTRY PURPOSES.

Secton 6. The Governor may, with the approval of a majority of the Board, after a hearing or hearings as licreinafter provicied, from time to time set apart any Government land or lanils not then under lease, or on which there is a lease of two years or less, as forest reservations. Any lands so set apart shall not thereafter be leased or sold by the Government, or used in any way or for any purposes inconsistent with this Act, except by law fully enacted by the Legislature.

SEction 7 . In all cases (not including roads and city lots), in which it shall be proposed under the provisions of Section 178 or 255 of the Civil Laws, by any person or official that any [mblic land or any interest therein, shall be disposed of either by way of quit-claim, sale, exchange, compromise or equitable settle. ment, no action shall be taken on such matter until the same shal! first have been referred to and approved by the Board, which. on receiving notice of any stuch proposed action, shall fully consider the same. If the Board shall then disapprove the proposed action it shall notify the Govenor accordingly and such proposed action shall not be taken.

\section{NOTICE OF HEARING.}

Section 8. Refore setting apart any Government lands under this section, the Governor shall give not less than fourteen days notice, by advertisement in not less than two newspaupers puh- 
lisined in this Territory, of intention to consider the setting apart of government land for forestry reservations under this Act, which notice or notices shall contain the name or names of the Island or Islands and of the district or districts in which the proposed forest reservation or reservations are located, and shall iurther appoint a time or times, place or places, for hearing evidence and arguments either for or against the setting apart of said proposed forcst reservations under this Act.

\section{HEARINGS.}

Section 9. At the time and place named for any such hearing or hearings a $f$ ull hearing shall be given by the Governor and the Board, to all who desire to be heard upon the.subject matter of the said notice. The hearing or hearings held in pursuance of said notice or notices shall be public, and shall be conducted unter such rules and regulations as the Governor in his discretion may direct Any such hearing may be continued, postponed or adjourned to such time or times, place or places as the Governor mat direct.

\section{IESTED RLGHTS}

Section io Provided, however, that nothing herein contained shall be held to in any way interfere or conflict with any vested rights uncler or arising out of any grant, grants, lease or leases, license or licenses, of or concerning any government land or water rights, or rights of way, heretofore made.

Nor shall anything herein contained be construed to change any riglits in or concerning any water upon or flowing from or t!rough any land set apart or surrendered as a forest reserve, or as depriving or limiting any Territorial officer from exercising any existing power or authority or any power which may hereafter be created to deal with said water or water rights, or rights of way.

\section{FOREST RESERVE ON PRIVATE LANDS.}

SECtion ri. Any person or persons, corporation of corpora- 
tions, may at any time surrender to the Government the care, custody and control of any lands, whether held under lease or in fee, as a forestry reservation, either for one or more years, or forever.

No taxes shall be levied or collected upon any private lands so surrendered for the purposes aforesaid, so long as the same shall remain exclusively under the control of the Government as a forestry reservation.

\section{SPECIAL FORESTRY FUND.}

SECTION i2. In case any moneys shall accrue from any forcstry reserve, or the products thereof, the same shall be deposited in the Treasury as a special fund for the preservation, extension and utilization of forests and forest reserves, and the same shall be there held available for use under this Act, subject to withdrawal and use in the same manner as moneys appropriated by the Legislature.

\section{IMPORTATION OF PLANTS, FRUIT, ETC.}

Section i3. No soil, nursery stock, tree, sugar cane, shrub, plant, flower, vine, cutting, graft, cion, bud, seed, root, fruit pit, fruit, vegetable, leaf, nut, or moss shall be imported into the Territory of Hawaii except in the manner, and upon the terms and conditions hereinafter set forth, viz.:

(I) Labels. A label shall be affixed to the article desired to be imported, or if it is enclosed, to the box, barrel, case, package or other container in which it is enclosed, which label shall set fortl! :

(a) The name, number or amount, and description of the said article or articles.

(b) The locality where the same was produced.

(c) The port from which the same was last shipped.

(d) The name of the shipper of sairl article or articles.

(c) The name of the consignee of said article or articles.

(2) Request fur Inspection. In addition to any requirements of the enstoms authorities concerning invoices or other formalities 
inciclent to importations into the Territory, the importer shall file a written statement with the Board, signed by himself, or his agent or attorney, which shall set forth his desire to import certain articles into the Territory, which articles shall be described as follows, viz.:

(a) The name, number or amount, and description of the said article or articles:

(b) The localtiy where the same was produced;

(c) The port from which the same were last shipped;

(d The name of the shipper thereof;

(e) The name of the consignee thereof.

The said statement shall also contain a request that the Board examine, or cause to be examined, the articles described as aforesaid, and agreeing to be and become responsible for all costs, charges and expenses incident to the inspection, examination, fumigation, disinfection, quarantine and care of said articles desired to be imported.

(3) Blanks. Suitable blanks shall be furnished by the Board, upon which to make such requests, which blanks may provide for the insertion of other statements, and may contain other requirements which the Board, in its discretion and under the authority herein contained to make rules and regulations, may direct.

(4) Inspection. Immediately upon receipt of a request for inspection, in accordance with the provisions hereinabove set forth, or as soon thereafter as reasonably practicable, an inspector of the Board shall inspect the said articles desired to be imported.

(5) Place of Inspection The said inspection may, in the discretion of the said Inspector, be made on the vessel importing the same, on the wharf adjacent thereo, or any other convenient place or places which he may indicate; but said article or articles shall in no case be removed from the vessel importing the same except upon a written permit signed by sair Inspector.

(6) Unpacking or Remoring. If, in the discretion of said Inspector, it is necessary, advisable or proper, in order to more fully inspect the said articles, to unpack the said articles, or any 
of them, or to remove them, or any of them, to any other place or places, he shall have authority so to do at the expense of the importer.

(7) Permit to Import. If, upon inspection as aforesaid, or at any time thereafter, if the said article or articles are held for further examination, the said Inspector shall be satisfied that the said articles clesired to be imported, or certain of them, are iree from insects, blight, scale and diseases injurious, or liable to become injurious, to trees, plants, or other vegetation of value, he shall give the importer a certificate of inspection, setting forth the date of the inspection or inspections, a description of the articles inspected, and permitting them to be imported into this Territory.

(8) Dlsunfection or Quarantine. If, in the opinion of said Inspector, it shall be necessary or proper for the better securing of the objects of this Act, to fumigate, disinfect or quarantirie said article or articles, or any of them, he shall have authority so to do, at the expense of the importer.

If, in the opinion of said Inspector, it shall be necessary or proper to hold said article for continued observation or treatment in order to be certain that no infection as aforesaid exists, or that any infection which exists or may exist therein may be eradicated, said Inspector may so hold said article or articles in quarantine for said purpose or purposes.

19) Destruction of Plants, Etc. If saicl Inspector shall at any time. either upon said first inspection or at any time thereafter while the said article or articles are being held as aforesaid, finc that the same or any of them, are infected with or contain any insect, blight, scale or cliscase injurious, or liable to become injurious, to trees, plants, or other vegetation of value, he shall, in his discretion, destroy the same or hold the same for further treatment.

(ro) What Constitutes Importation. The landing of any article as aforesaid, for the purpose of inspection or quarantine, shall not be, nor be construed to be, an importation for the purpose of giving to the article or articles so landed any status, or the owner thereof any rights or privileges incident to the articles 
which have been imported into the Territory; but in legal effect the articles so landed for purposes of inspection shall be construed to still be without the Territory, seeking entry into the Territory, and shall not, in whole or in part, be entitled to be imported into this Territory until a permit so to do, as aforesaid, shall have been issued by the Board or Officer or Inspector thereof.

(II) Exceptions to Right to Import. Nothing in this Act contained shall permit the importation of any article, or class of articles, or any article or class of articles from any particular place, if the same, or any of them, have, by special rule or regulation of the Board, as hereinbefore provided, been prohibited from importation into this Territory.

(12) Port of Importation of Plants. No nursery stock, soil, tree, sugar cane, shrub, plant, flower, vine, cutting, graft, cion, bud, seed, root, leaf, nut, moss, or other vegetable growth (except hay, grain, fruit, vegetables and nuts for immediate consumption) shall be imported into the Territory of Hawaii, saving and excepting through the port of Honolulu only.

$$
\text { SOILS. }
$$

Section I4. No soil, sand, or rocks or stone having soil adhering thereto, brought to this Territory as ballast, or separate from the roots of plants, trees or other vegetation, except such as are suitable for, and intended to be used as, or in the mantfacture of fertilizer, or for building, mechanical or monumental purposes, shall be allowed to be landed in this Territory. If any vessel comes to this Territory with soil, sand, rocks or stones having soil adhering thereto, on board as ballast or in bulk, and it is clesired to remove the same, it shall, except as aforesaid, be dumped at sea.

No soil or sand brought to this Territory in connection with or around the roots of plants, trees or other vegetation, or rocks or stones with soil or sand adhering to them, shall be allowed to be imported into this Territory, until the same shall have been removed to a suitable place for inspection and quarantine, and there held for such length of time as, in the discretion of the Board or its Officers or Agents, shall be necessary to prove that it is not 
infected with insects, blights, scales, or diseases injurious to trees, plants or other vegetation of value.

\section{FEES FOR INSPECTION, QUARANTINE, ETC.}

Section 15. The Board shall, with the approval of the Governor, adopt a reasonable scale of charges, which may be changed from time to time, for the inspection, disinfection, fumigation and quarantine, authorized, required or permitted by this Act. Certificates and permits herein provided for concerning articles imparted, or proposed to be imported, into this Territory, and the charges so provided for, shall be paid for in advance before any certificate or permit is delivered, or any of said articles are permitted to be landed. If thereafter further expense is incurred in the inspection, treatment or quarantine of any of said articles, the charges therefor shall be paid before any of said articles shall be deivered.

\section{PENALTY.}

Section i6. Any person violating any of the provisions of this Act, and any Master of any vessel which shall bring into this Territory any article which the Board shall at any time prohibit from being imported into this Territory; and the Master of any vessel from which shall be landed any article in this Act required to be inspected, until he shall have received a permit to land the said articles from the Board or its Officer or Inspector, as herein provided, shall be guilty of a misdemeanor, and shall be punished by a fine not to exceed $\$ 500$, or imprisonment as aforesaid, in the discretion of the Court.

\section{RIGHT OF APPEAL.}

Section i7. Any person who shall feel aggrieved at any decision of any Inspector of the Board shall have the right to appeal from such clecision to the Board. The Board shall give a prompt hearing to the appellant and the Inspector upon such appeal, and decirle the question at issue, which decision shall be final. 
EXPENDITURES.

SECTION I8. All persons authorized to be employed by the Board, and all expenditures authorized to be made by the Board. except salaries and expenditures specially fixed by the Legislature, shall be paid out of the general appropriation for Agriculture and Forestrv.

\section{ASSISTANCE.}

Section 19. The Board shall, so far as reasonably practicable, assist, free of cost to individuals, in the eradication of insects, blights, scale, and diseases injurious to vegetation of value; and shall in like manner distribute to points where needed, insects, growths and other antidoes for the eradication of insects, blights, scales and diseases injurious to vegetation of value, and for the eradication of vegetation of a noxions character.

\section{GENERAL POWERS.}

Section 20. For the purpose of consolidating the powers and anthority relating to kindred matters, the powers and duties heretofore vested in the Commissioner of Agriculture and Forestry, are hereby transferred to and vester in the Superintendent of Public Works, who shall be the executive officer of the Board, subject to the superintendence and control of the Board.

The Board shall also have superintendence and control of the execution and enforcement of all other existing statutes relating to Agriculture and Forestry, and all other matters which may hereafter be placed within their jurisdiction by the Legislature.

Approved this 25th day of April, 1903.

SANFORD B. DOLE, Governor of the Territory of Hawaii. 


\section{BOARD OF \\ Agriculture, Horticulture and Forestry}

$\rightarrow A N D:-$

APPROPRIATIONS FOR SAME PASSED BY THE LEGISLATURE OF 1903.

Salaries and Pay Rolls, Six Months to Dec. 31, 1903-

Pay of Superintendent of For-

estry . . . . . .

Assistants, Rangers (to include 1

Ranger for Molokai), Em-

ployees and Laborers of Di-

vision of Forestry........ $6,000.00$

Pay of Superintendent of Einto-

mology ........... $\quad 1,500.00$

Pay of Assistant Entomologists.. $\quad 2,500.00$

Assistants, Tnspector's and Em-

ployees of Division of Ento-

mology .......... $1,500.00$

Pay of Clerk and Messenger .... $\quad 300.00$

Pay of Stenographer and Type-

writer ............ 600.00

Federal Experiment Station-

Chemist............... \$ 500.00 


\section{Current Expenses.}

Incidentals and General Expenses of Board, including importation, collection and propagation of Seeds and Plants.....\$2,000 00 Apparatus and Library ...... $\quad 250.00$ 'I'raveling Expenses of Commissioner's . . . . . . . . . .

Incidentals, General Fxpenses and Maintenance of Division of Forestry, including fencing, building and tree propagation Traveling Expenses, Superintendent of Forestry .......... 250.00

Incidentals. General Expenses and Maintenance of Division of Entomology, including buildings, disinfecting and ciuarantine expenses and material, importation, propagation and distribution of beneficial insects, and Traveling Expenses of Entomologists. . . . . . . . . $2,500.00$

Farmers' Institute ........... 75.00 Agricultural and Horticultural Fairs . . . . . $1,250.0 \ldots \ldots \ldots .6$ Assistance to Federal Experiment Station at Honolulu, to be expended under the direction of the Board ........... 2,500.00

Forwurd, $\begin{array}{r}\$ 13,95000 \\ \$ 28,350.00 \\ \hline\end{array}$


Brought Forward,

BOARD OF AGRICULTURE, HORTICULTURE AND FOR. ESTRY.

Salaries and Pay Rolls Eighteen Months to June 30, 1905--

Salary of Superintendent of For-

estry............. $4,500.00$

Assistants, Laborers and Rangers,

Division of Forestry...... $15,000.00$

Salary of Superintendent of En-

tomology ......... $\quad 4,500.00$

Pay of Assistant Entomologists. $\quad 7,500.00$

Pay of Assistants, Inspectors and

Employees, Division of En-

tomology . . . . . . . . . .

Pay of Clerk and Messenger.... 900.00

Federal Experiment Station.

Chemist . . . . . . . . $1,500.00$

\section{Current Expenses.}

Incidentals and General Expenses

of Board, including importa-

tion, collection and distribu-

tion of seeds and plants....\$

Apparatus and Library ........

$6,000.00$

Travelling Expenses of Commissioners . ................

Incidentals, General Expenses and Maintenance of Division of Forestry, including buildings, fencing and tree propagation............. \$ $\quad 15,000.00$

Travelling Expenses, Superintendent of Forestry ........ 750.00 
Brought Forward, $\$ 22,875.00 \quad \$ 38,40000$

Incidentals, General Expenses and Maintenance of Division of Entomology, including buildings, disinfecting and quarantine expenses and material; importation, propagation and distribution of beneficial insects, and travelling expenses of Entomologists .. Agricultural and Horticultural Fairs . ................ Farmers' Institute ........... Assistance to Federal Experiment Station at Honolulu ........ $7,500.00$ $3,500.00$ 225.00

$\begin{array}{r}7,500.00 \quad \$ 41,600.00 \\ -\$ 80,000.00 \\ \hline\end{array}$

BOARD OF AGRICULTURE, HORTICULTURE ANI) FORESTRY.

Six months to December $31,1903 \ldots \$ 28,350.00$

Eighteen months to June 30, 1905. $\quad 80,000.00$

$\$ 108,350.00$ 



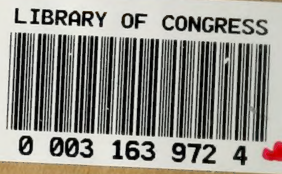

